\title{
Clonal analysis of lung and blood T cells in patients with sarcoidosis
}

\author{
M J Garlepp, A H Rose, J E Dench, B W S Robinson
}

\begin{abstract}
Background - Sarcoidosis is a disease characterised by clinical "anergy" to delayed type hypersensitivity antigens and the formation of non-caseating granulomas, which frequently manifests in the lungs as a $T$ lymphocyte/mononuclear cell alveolitis. Although there is an increased proportion of $T$ cells in bronchoalveolar lavage (BAL) samples from these patients, and these $T$ cells often show evidence of activation and spontaneous secretion of cytokines such as interleukin 2 (IL-2) and interferon gamma (IFN $\gamma$ ) - a pattern similar to delayed type hypersensitivity reactions it is unclear whether both cytokines are produced by the majority of $T$ cells derived from the lungs of patients with sarcoidosis or whether unique subpopulations of $\mathbf{T}$ cells produce each cytokine. In this study the properties of $T$ cells cloned from BAL fluid samples of patients with sarcoidosis have been analysed.

Methods - T cells were cloned by limiting dilution using IL-2, phytohaemagglutinin, and irradiated feeder cells. Cloning efficiencies were compared and phytohaemagglutinin induced clonal production of IL-2, IFN $\gamma$, and IL-4 was determined by bioassay (IL-2 and IFN $\gamma$ ) or ELISA (IL-4).
\end{abstract}

Results - T cells derived from the BAL fluid of patients with sarcoidosis cloned less efficiently than those from blood of the same individuals. Lung derived clones (CD4+ or CD8 +) produced IFN $\gamma$ more frequently and to a higher titre than blood derived clones, whereas IL-2 production by $\mathrm{CD} 4+$ clones derived from BAL fluid was less than that from blood derived clones. Interestingly, IL-4 production by clones from both sites was similar. Analysis of the coproduction of IL-2, IFN $\gamma$, and IL-4 by these BAL fluid clones did not demonstrate a predominant "Th1"-like population which has been suggested to underlie delayed type hypersensitivity reactions.

Conclusions - The reduced cloning efficiency of $T$ cells from the lung compared with the blood in sarcoidosis is consistent with, although probably more pronounced than, previous observations in normal lungs and shows that $T$ cell hyporesponsiveness is not overcome in the lungs of patients with sarcoidosis. Furthermore, major differences exist between the cytokine producing potential of $T$ cells derived from the lung and the blood in sarcoidosis, and these parallel the differences in the properties of blood and lung $T$ cells seen in healthy individuals.

(Thorax 1994;49:577-585)

Sarcoidosis manifests in the lungs as a $T$ lymphocyte/mononuclear phagocyte alveolitis and a granulomatous response which may result in irreversible damage to the lung parenchyma. ${ }^{1}$ In bronchoalveolar lavage (BAL) samples there is an increased proportion of lymphocytes and, in active disease, usually an increase in the ratio of $\mathrm{CD} 4+$ to $\mathrm{CD} 8+\mathrm{T}$ cells. ${ }^{23} \mathrm{~T}$ cells associated with the granulomas in lung biopsies and BAL samples often express interleukin 2 receptors (IL-2R) and other markers of activation such as HLADR. ${ }^{45}$ Furthermore, these $T$ cells in BAL fluid spontaneously secrete cytokines such as IL-2, interferon gamma (IFN $\gamma$ ), and monocyte chemotactic factor. ${ }^{6-9}$ These data suggest an ongoing $T$ cell response. The stimulating agent or antigen is unknown, but the cytokines released are thought to facilitate recruitment of mononuclear cells and granuloma formation, ${ }^{9}$ and it seems likely that CD4 $+\mathrm{T}$ cells are intimately involved in this process.

Murine CD4+ $\mathrm{T}$ cell clones have been divided into "Th1" cells which produce IL-2, IFN $\gamma$, and lymphotoxin and mediate delayed type hypersensitivity responses, and "Th2" cells which produce IL-4, IL-5, and IL-6 and provide help for $B$ cell differentiation and immunoglobulin production. ${ }^{10}$ Although this division is yet to be conclusively demonstrated for human T cells, some evidence has accumulated to support the existence of such subpopulations. ${ }^{11-13}$

The profile of cytokines produced spontaneously by lung $T$ cells from patients with sarcoidosis - that is, IL-2, IFN $\gamma$ - and the characteristic presence of granulomas reminiscent of foci of delayed type hypersensitivity reactivity, suggest that the $\mathrm{CD} 4+$ cells infiltrating sarcoid lungs may be of the Th1 type. Previous studies of $T$ cells obtained from the BAL fluid and blood of patients with pulmonary sarcoidosis have largely concentrated on whole populations rather than individual $T$ cell responses. It is, however, unknown whether separate populations of T cells produce IFN $\gamma$ and IL-2 or whether both cytokines are produced by a single population of $\mathrm{T}$ 
cells. Further, it is unclear whether most of the $T$ cells in the lungs of patients with sarcoidosis are capable of producing these cytokines, or whether a relatively minor subpopulation is responsible for their secretion.

We have recently shown major differences in the cytokine producing capacity of $\mathrm{T}$ cell clones derived from healthy lungs compared with those derived from peripheral blood of the same subjects. ${ }^{14}$ In the work reported here we compare the properties of $\mathrm{T}$ cells clonable from the lungs of patients with sarcoidosis with those derived from autologous blood.

\section{Methods}

STUDY POPULATION

Nine patients who fulfilled standard criteria for the diagnosis of sarcoidosis ${ }^{15}$ were studied. Clinical and physiological data for each patient at the time of lavage are presented in table 1. All patients were non-smokers. $T$ cell clones were also derived from nine healthy volunteers (eight men, one woman; six non-smokers, two ex-smokers, and one smoker) of mean (SD) age 54 (10) years in an overlapping study. Data on these subjects have been published previously ${ }^{14}$ save for those on IL-4 production by CD8 + clones which are presented here. The study was approved by the Human Rights Committee of the University of Western Australia.

\section{PREPARATION OF BAL FLUID AND PERIPHERAL BLOOD CELLS}

Bronchoalveolar lavage was performed as previously described. ${ }^{16}$ Briefly, the bronchoscope was passed transorally and wedged in a subsegmental bronchus. Six $50 \mathrm{ml}$ aliquots of warm $\left(37^{\circ} \mathrm{C}\right)$ saline solution were infused into the lung and recovered immediately into disposable sterile polycarbonate bottles. The first aliquot was analysed separately and the remaining five were pooled and used as the "alveolar cell" sample. The volume and appearance of this sample were recorded and the cells were concentrated by centrifugation at $400 \mathrm{~g}$ for seven minutes. Cell viability was determined by trypan blue exclusion and differential cell counts were performed on 400 cells stained with May-Grunwald-Giemsa stain $\left(10^{5}\right.$ cells per slide). Blood from each patient was collected in heparinised tubes at the time of lavage and mononuclear leucocytes isolated using Ficoll-Paque (Pharmacia Fine Chemicals, Uppsala, Sweden) density centrifugation.

T CELL CLONING BY LIMITING DILUTION

$T$ cells were purified from BAL fluid and blood samples by adherence and rosetting with sheep erythrocytes and seeded into round bottomed 96 well microtest plates (Nunc, Roskilde, Denmark) at densities of $0 \cdot 25,0.5,1,2$, 4,8 , and 16 cells per well in a total volume of $200 \mu 1$ RPMI-1640 (Flow Laboratories, North Ryde, Australia) containing 15\% human AB serum, $1 \mu \mathrm{g} / \mathrm{ml}$ phytohaemagglutinin (Wellcome, UK), $100 \mathrm{U} / \mathrm{ml}$ IL-2 (Cetus, Emeryville, California, USA), and $10^{5}$ irradiated feeder cells. Feeder cells were either irradiated (5000 rad) freshly prepared autologous or allogeneic blood mononuclear cells or human spleen cells ( $3000 \mathrm{rad}$ ) which had been stored, cryopreserved, and cultured overnight in phytohaemagglutinin before use. Fresh media and feeder cells were added at day 7 and positive wells were scored on day 12 . The fraction of non-responding wells was plotted against the number of cells seeded per well on a semilogarithmic plot and precursor frequencies were determined according to the zero order term of the Poisson probability distribution. Positive wells were expanded from plates showing $T$

Table 1 Clinical, physiological, and bronchoalveolar lavage data for individual patients with sarcoidosis

\begin{tabular}{|c|c|c|c|c|c|c|c|c|c|c|c|}
\hline \multirow[b]{2}{*}{$\begin{array}{l}\text { Patient } \\
\text { no. }\end{array}$} & \multirow[b]{2}{*}{ Sex } & \multirow[b]{2}{*}{$\begin{array}{l}\text { Age } \\
\text { (years) }\end{array}$} & \multirow[b]{2}{*}{$\begin{array}{l}\text { Disease } \\
\text { duration } \\
\text { (years) }\end{array}$} & \multirow[b]{2}{*}{ Treatment* } & \multirow[b]{2}{*}{$\begin{array}{l}\text { Chest } \\
\text { radiography }{ }^{\dagger}\end{array}$} & \multirow[b]{2}{*}{ TLCO } & \multirow[b]{2}{*}{$G a_{+}^{+}$} & \multicolumn{4}{|c|}{$\begin{array}{l}\text { BAL fluid differential count } \\
(\%)\end{array}$} \\
\hline & & & & & & & & $M$ & $L$ & $N$ & $E$ \\
\hline 1784 & $\mathrm{~F}$ & 50 & 16 & Nil & $\mathbf{N}$ & 113 & \multirow{10}{*}{$\begin{array}{l}4 \cdot 2 \\
\mathrm{~L}+\mathrm{N}+ \\
\mathrm{NM} \\
3 \cdot 4 \\
\mathrm{~L}+\mathrm{N}- \\
3 \cdot 8 \\
\mathrm{~L}+\mathrm{N}+ \\
5 \cdot 2 \\
\mathrm{~L}+\mathrm{N}- \\
4 \cdot 5 \\
\mathrm{~L}+\mathrm{N}+ \\
7 \cdot 2 \\
\mathrm{~L}+\mathrm{N}- \\
3 \cdot 2 \\
\mathrm{~L}+\mathrm{N}- \\
3 \cdot 1 \\
\mathrm{~L}+\mathrm{N}- \\
4 \cdot 3 \\
(1 \cdot 4) \\
2 \cdot 0\end{array}$} & $88 \cdot 0$ & $11 \cdot 7$ & 0.3 & 0.0 \\
\hline $\begin{array}{l}1744 \\
1580\end{array}$ & $\begin{array}{l}\mathrm{F} \\
\mathrm{M}\end{array}$ & $\begin{array}{l}29 \\
29\end{array}$ & $\begin{array}{l}0 \cdot 3 \\
3\end{array}$ & $\begin{array}{l}\text { Nil } \\
\text { Pred }\end{array}$ & $\begin{array}{l}\text { II } \\
\text { III }\end{array}$ & $\begin{array}{l}110 \\
78\end{array}$ & & $\begin{array}{l}43 \cdot 8 \\
80 \cdot 2\end{array}$ & $\begin{array}{l}52 \cdot 6 \\
16 \cdot 2\end{array}$ & $\begin{array}{l}3 \cdot 5 \\
3 \cdot 6\end{array}$ & $\begin{array}{l}0.0 \\
0.0\end{array}$ \\
\hline 1777 & $\mathbf{F}$ & 31 & $0 \cdot 1$ & Nil & I & 84 & & $68 \cdot 0$ & $29 \cdot 7$ & $2 \cdot 3$ & 0.0 \\
\hline 1555 & $\mathbf{F}$ & 68 & 5 & Nil & III & 64 & & $56 \cdot 5$ & $41 \cdot 4$ & $1 \cdot 3$ & 0.0 \\
\hline 1705 & $\mathbf{F}$ & 53 & 10 & Nil & I & 78 & & $68 \cdot 3$ & $30 \cdot 0$ & $1 \cdot 8$ & $0 \cdot 0$ \\
\hline 1745 & $\mathbf{F}$ & 50 & 8 & Nil & III & 68 & & $85 \cdot 1$ & $12 \cdot 9$ & 0.3 & $2 \cdot 0$ \\
\hline 1793 & $\mathbf{M}$ & 35 & 6 & Nil & III & 80 & & $88 \cdot 6$ & $10 \cdot 1$ & $1 \cdot 3$ & $0 \cdot 0$ \\
\hline 1867 & $\mathbf{F}$ & 42 & 6 & Nil & III & 85 & & $32 \cdot 6$ & $64 \cdot 4$ & $3 \cdot 0$ & $0 \cdot 0$ \\
\hline \multicolumn{6}{|c|}{ Mean (SD) } & $\begin{array}{l}84 \cdot 9 \\
(16 \cdot 9)\end{array}$ & & $\begin{array}{l}67 \cdot 9 \\
(20 \cdot 1)\end{array}$ & $\begin{array}{l}29 \cdot 9 \\
(19 \cdot 5)\end{array}$ & $\begin{array}{l}1.9 \\
(1 \cdot 3)\end{array}$ & $\begin{array}{l}0.2 \\
(0.7)\end{array}$ \\
\hline \multicolumn{6}{|c|}{ Normal (SD) values§ } & 100 & & $\begin{array}{l}79 \cdot 7 \\
(10 \cdot 9)\end{array}$ & $\begin{array}{l}17 \cdot 4 \\
(9 \cdot 7)\end{array}$ & $\begin{array}{l}2 \cdot 4 \\
(1 \cdot 9)\end{array}$ & $\begin{array}{l}0 \cdot 3 \\
(0 \cdot 4)\end{array}$ \\
\hline
\end{tabular}


cell growth in less than $30 \%$ of wells giving a probability of clonality of $>0 \cdot 793 .{ }^{1417}$ Clones were maintained by biweekly feeding with RPMI supplemented with $10 \%$ human $A B$

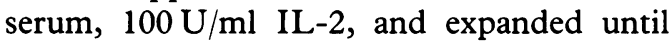
sufficient cells were available for analysis.

\section{INDIRECT IMMUNOFLUORESCENCE}

Hybridoma lines OKT3 (CD3), OKT4 (CD4), and OKT8 (CD8) were obtained from the American Type Culture Collection (ATCC) (Rockville, Maryland, USA), cultured in this laboratory and, after screening, the culture supernatants were used unpurified. Unfractionated blood and BAL fluid $T$ cell preparations and the clones generated from these preparations were phenotyped by indirect immunofluorescence using the above antibodies. ${ }^{14}$ Fluoresceinated sheep antimouse antibody (Silenus, Melbourne, Australia) was used as the detection system.

\section{INDUCTION OF CYTOKINES}

Cloned $\mathrm{T}$ cells were seeded at a density of $10^{6}$ cells $/ \mathrm{ml}$ in $200 \mu \mathrm{l}$ RPMI with $10 \%$ human $\mathrm{AB}$ serum in 96 well round bottomed microtitre trays (Linbro, Flow Laboratories, USA) and stimulated with $1 \mu \mathrm{g} / \mathrm{ml}$ phytohaemagglutinin. Supernatants were collected after 24 hours and frozen at $-80^{\circ} \mathrm{C}$ until assayed.

\section{CYTOKINE ASSAYS}

IL-2 was assayed as previously described ${ }^{18}$ using the IL-2 dependent cell line CTLL-2 (ATCC, TIB 214). Units of IL-2 were read from a standard curve generated using human recombinant IL-2 (Cetus). IFN $\gamma$ was measured using an antiviral bioassay as previously described. ${ }^{19}$ The reciprocal of the sample dilution which produced a $50 \%$ inhibition of the cytopathic effect of encephalomyocarditis virus on human Wish cells (ATCC, CCL25) was determined and the activity was calculated by comparison with the effect of a recombinant IFN $\gamma$ standard (BoehringerIngelheim, Ingelheim Am Rhein, Germany). IFN activity was confirmed to be gamma in type by preincubating samples with antibody to IFN $\gamma$ (Meloy Laboratories, Springfield, Virginia, USA). IL-4 was assayed using a commercially available ELISA kit (Genzyme, Boston, USA). The sensitivities of the assays for IFN $\gamma$, IL-2, and IL-4 were $2 \mathrm{U} / \mathrm{ml}, 0.2 \mathrm{U} /$ $\mathrm{ml}$, and $0 \cdot 1 \mathrm{ng} / \mathrm{ml}$, respectively. Cytokine production was considered to be significant when the quantity measured was greater than $3 \mathrm{SD}$ above the mean value for feeder cells alone, processed in the same manner as the clones. These cutoffs were $>4 \mathrm{U} / \mathrm{ml}(\mathrm{IFN} \gamma),>2 \mathrm{U} /$ $\mathrm{ml}$ (IL-2), and $>0 \cdot 16 \mathrm{ng} / \mathrm{ml}$ or $4 \mathrm{U} / \mathrm{ml}$ (IL-4).

\section{STATISTICAL ANALYSIS}

Cloning efficiencies and cytokine levels were compared using the Wilcoxon rank sum test and $p$ values of $<0.05$ were regarded as statistically significant.

\section{Results}

CELLULAR CONTENT OF BAL FLUID AND BLOOD

The total cell yield and the volume of lavage fluid recovered from patients with sarcoidosis were similar to those obtained by lavage of normal subjects (data not shown). The percentage of lymphocytes in the BAL fluid varied from $10 \%$ to $64 \%$. The percentage of $\mathrm{CD} 4+\mathrm{T}$ cells in the BAL fluid from patients with sarcoidosis varied from $50 \%$ to $100 \%$, compared with $33-52 \%$ in the peripheral blood.

\section{CLONING EFFICIENCY}

$T$ cells derived from BAL fluid of patients with sarcoidosis cloned far less efficiently than those derived from the blood $(p<0.005$, Wilcoxon rank sum). In all cases the $T$ cell precursor frequency in BAL samples was less than that in the blood of the same subject (fig 1). Blood derived $T$ cells from patients with sarcoidosis were as readily clonable as those from healthy individuals ${ }^{14}$ (median precursor frequency 6.2 compared with 6.3 for normals ${ }^{14}$ ). $T$ cells from the BAL fluid samples of patients with sarcoidosis were less readily clonable than those from the BAL fluid of healthy subjects ${ }^{14}$ using identical methods and performed during the same time period (median precursor frequency for BAL samples from sarcoid patients $47 \cdot 3$ compared with $20 \cdot 5$ for normals ${ }^{14}$ ).

\section{SURFACE PHENOTYPE}

The number of CD4 + clones derived from BAL fluid samples from patients with sarcoidosis ranged from five to 38 (mean $17 \cdot 5$ ), and from the blood of patients with sarcoidosis the range was four to 59 (mean 22.5). CD8+ clones were less common, the range for $\mathrm{BAL}$ fluid being one to 16 (mean four) and for blood one to 15 (mean six). A total of $161 \mathrm{BAL}$ fluid derived and 209 blood derived CD4 + clones were analysed along with 37 BAL fluid derived and 54 blood derived CD $8+$ clones. The mean proportions of $\mathrm{CD} 4+$ and $\mathrm{CD} 8+$ clones generated from BAL fluid samples from patients with sarcoidosis did not differ signi-

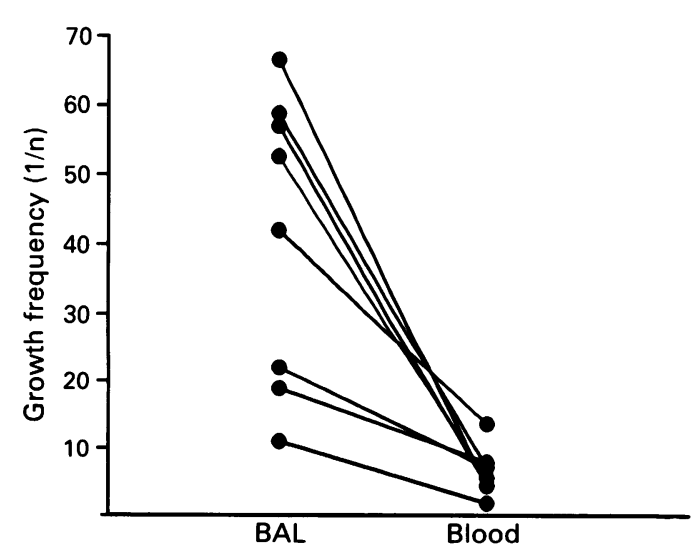

Figure 1 Cloning frequencies for $T$ cells cloned from $B A L$ fluid and blood of patients with sarcoidosis. The data are plotted as the number of starting cells which yield a single $T$ cell clone $(1 / n)$. 
ficantly from the proportions present in the starting populations, although $\mathrm{CD} 4+\mathrm{T}$ cells were more readily clonable than $\mathrm{CD} 8+$ cells from the blood of patients with sarcoidosis (fig 2).

CYTOKINE SYNTHESIS BY CD $4+$ CLONES

As the cytokine producing potentials of CD4+ and $\mathrm{CD} 8+$ cells are known to differ, and in view of potential heterogeneity within the $\mathrm{CD} 4+$ population, $\mathrm{CD} 4+$ and $\mathrm{CD} 8+$ clones were analysed separately. Eight of the nine subjects yielded sufficient CD4+ clones to allow comparison of the properties of clones derived from BAL fluid and blood within individuals. In seven subjects IFN $\gamma$ production by clones derived from BAL fluid was greater than that by blood derived clones $(p<0.01)$, and in one the difference was not statistically significant (fig 3A). IL-2 production was less in clones derived from BAL fluid than in those derived from blood $(p<0.02)$ in each of five subjects and not significantly different in three (fig 3B). The pooled data clearly indicated that $\mathrm{CD} 4+$ clones derived from BAL fluid of patients with sarcoidosis produced significantly more IFN $\gamma(\mathrm{p}<0.0005)$ and significantly less IL-2 $(\mathrm{p}<0.0005)$ than those derived from blood of patients with sarcoidosis (data not shown). By contrast, production of IL-4 by CD 4 + clones derived from blood and BAL fluid differed in only one subject (data not shown).

IL-2 AND IFN $\gamma$ SYNTHESIS BY CD8 + CLONES Insufficient CD8 + clones were available from each patient to allow meaningful individual analyses so only pooled data were compared (fig 4). Clones derived from BAL fluid produced higher concentrations of IFN $\gamma$ than those from blood $(p<0.02)$. The distributions of IL-2 (fig 4) and IL-4 (data not shown) concentrations were not significantly different.

CYTOKINE COMBINATIONS

In an effort to define subsets of CD $4+T$ cells we analysed the clones according to the com- binations of the cytokines which they were capable of producing. When production of IL2 plus IFN $\gamma$, a widely used phenotypic feature of Thl clones, was analysed it became clear that very few $\mathrm{CD} 4+$ clones from BAL fluid produced IL-2 without IFN $\gamma$, although many produced IFN $\gamma$ without IL-2 (fig 5). By contrast, a very large proportion of blood derived clones produced IL-2 without IFN $\gamma$, and a lesser number produced IFN $\gamma$ without IL- 2 . Many clones from both sources were capable of producing both cytokines.

When the clones were analysed for the coproduction of IL-4 and IFN $\gamma$, a phenotypic feature of "Th0" but not Th1 or Th2 cells, it became clear that a higher proportion of clones derived from blood than from BAL fluid produced IL-4 without IFN $\gamma(48 \% v 11 \%$ ) (fig 5). Importantly, a high percentage of clones from both sources produced both IL-4 and IFN $\gamma$ (59\% and 40\%, respectively).

A similar comparison of IL- 4 and IFN $\gamma$ production by the CD 8 + clones revealed very few clones, derived from either blood or BAL fluid, which produced IL-4 alone and larger proportions which either produced IFN $\gamma$ alone or both cytokines. These findings are consistent with those for CD8 + clones from the BAL fluid and blood of healthy individuals (fig 6).

\section{Discussion}

Despite the apparent heightened "activation" of $T$ cells derived from the BAL fluid of patients with sarcoidosis ${ }^{4-9}$ in comparison with those from normal individuals and from autologous blood, this study shows that the $T$ cells have a reduced response to $T$ cell mitogens under the cloning conditions used here. This is consistent with the observation of reduced responses of $\mathrm{T}$ cells from BAL fluid of patients with sarcoidosis to common recall antigens such as purified protein derivative and Candida antigen. ${ }^{20}$ The reduced cloning efficiency of $\mathrm{T}$ cells derived from BAL fluid, compared with blood, of healthy individuals ${ }^{14}$ is thus not overcome in the lungs of patients with sarcoidosis. This
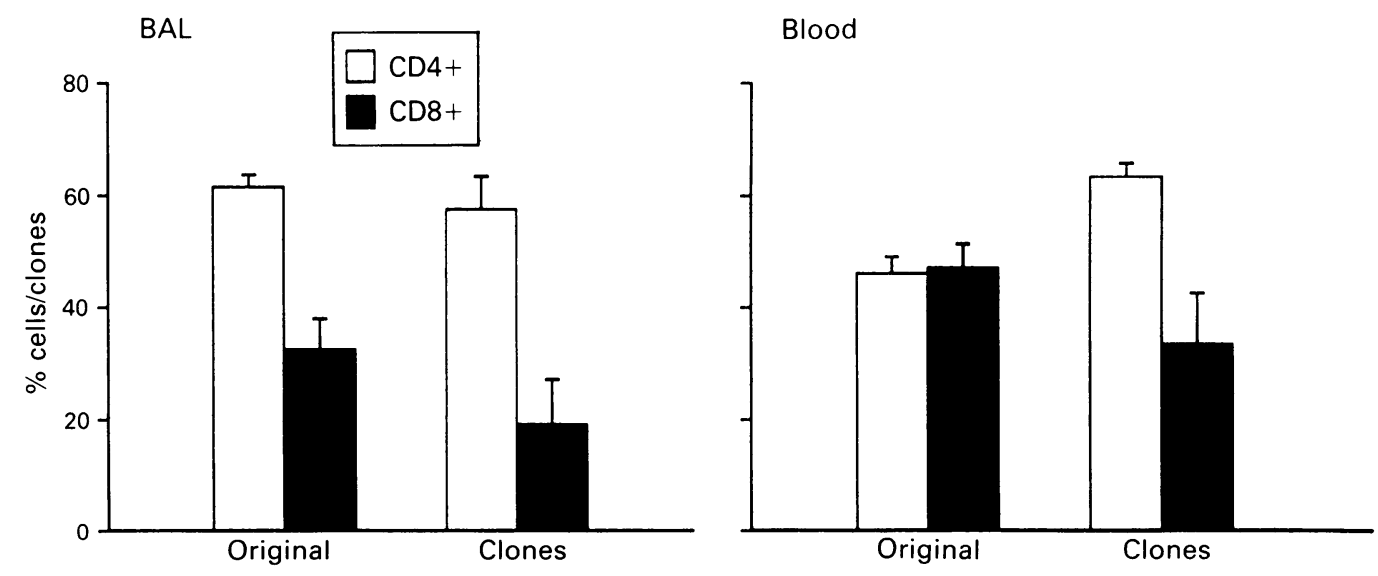

Figure 2 Phenotypes of starting $T$ cell populations and resultant clones derived from BAL fluid and blood of patients with sarcoidosis (graphs show mean (SE)). 

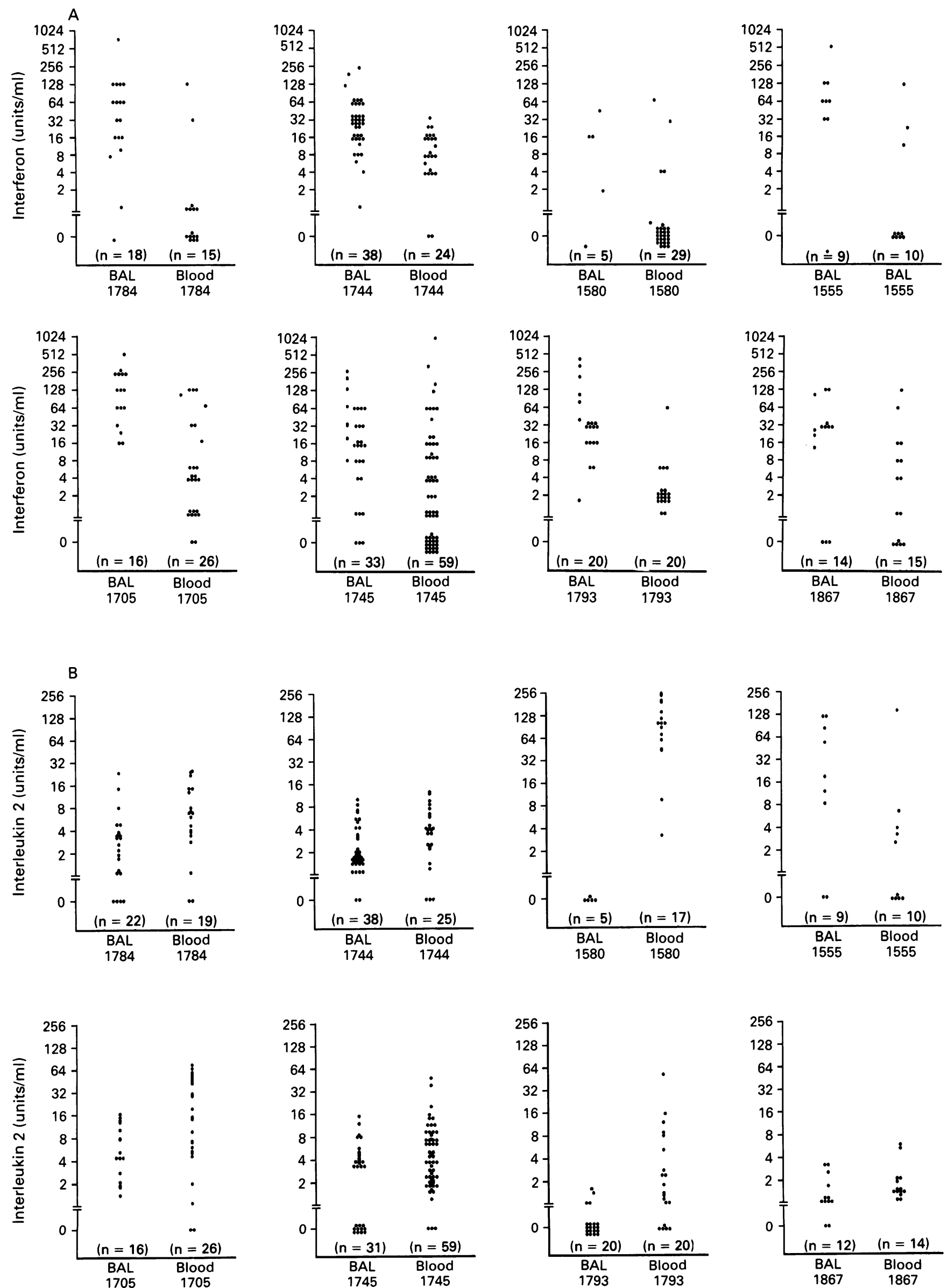

Figure 3 (A) IFN production by $T$ cell clones derived from BAL fluid or blood of patients with sarcoidosis. Comparisons between BAL fluid and blood derived clones were made using the Wilcoxon rank sum test. Clones derived from BAL fluid produced more IFN $\gamma$ than those from blood $(p<0.01)$ in all subjects except 1867 . (B) IL-2 production by $T$ cell clones derived from BAL fluid or blood of patients with sarcoidosis. Blood derived clones produced more IL-2 than those from BAL fluid $(p<0.02)$ in all subjects except 1555, 1745, and 1867. 

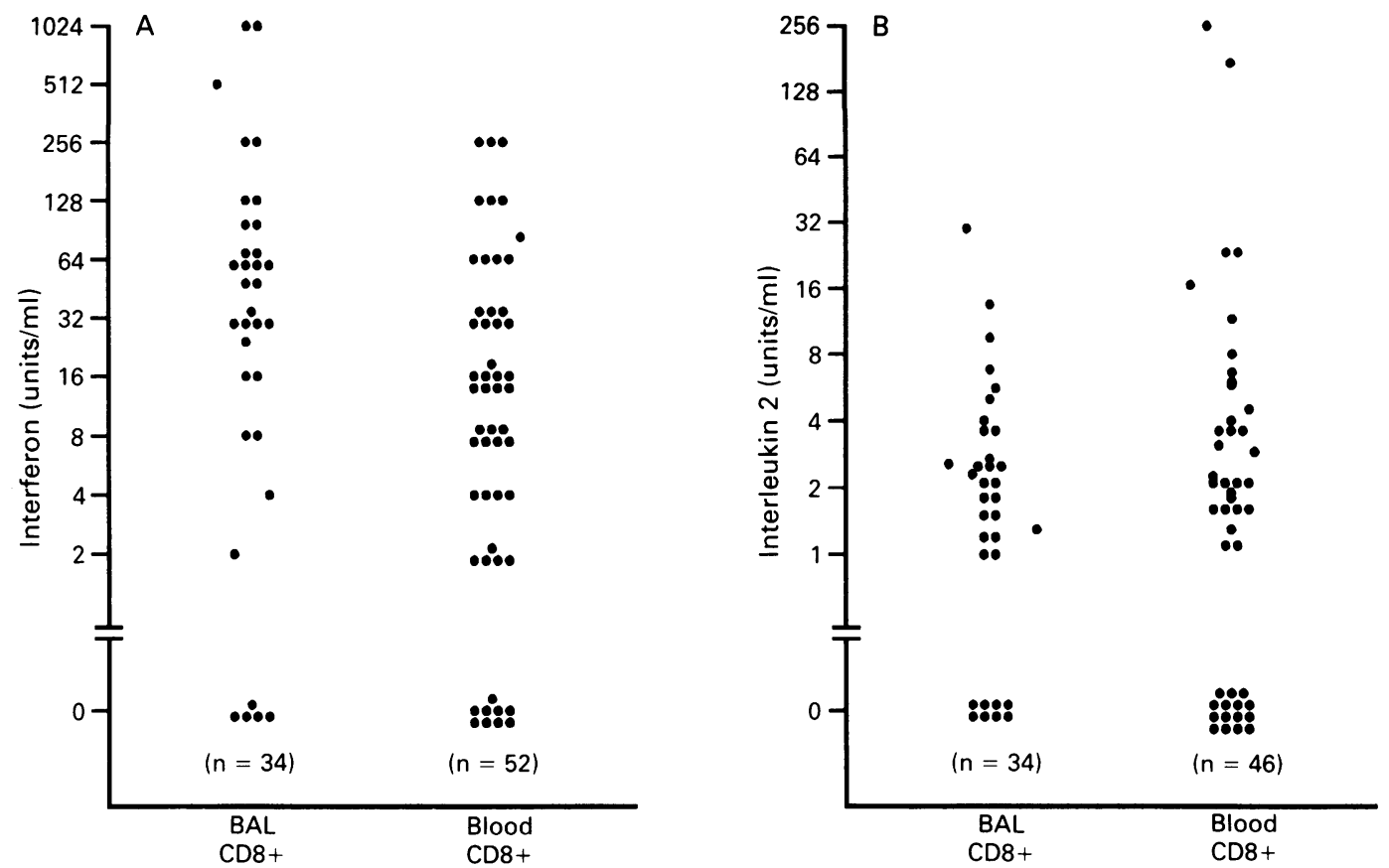

Figure 4 (A) IFN $\gamma$ and (B) IL-2 production by $C D 8+$ clones derived from patients with sarcoidosis.
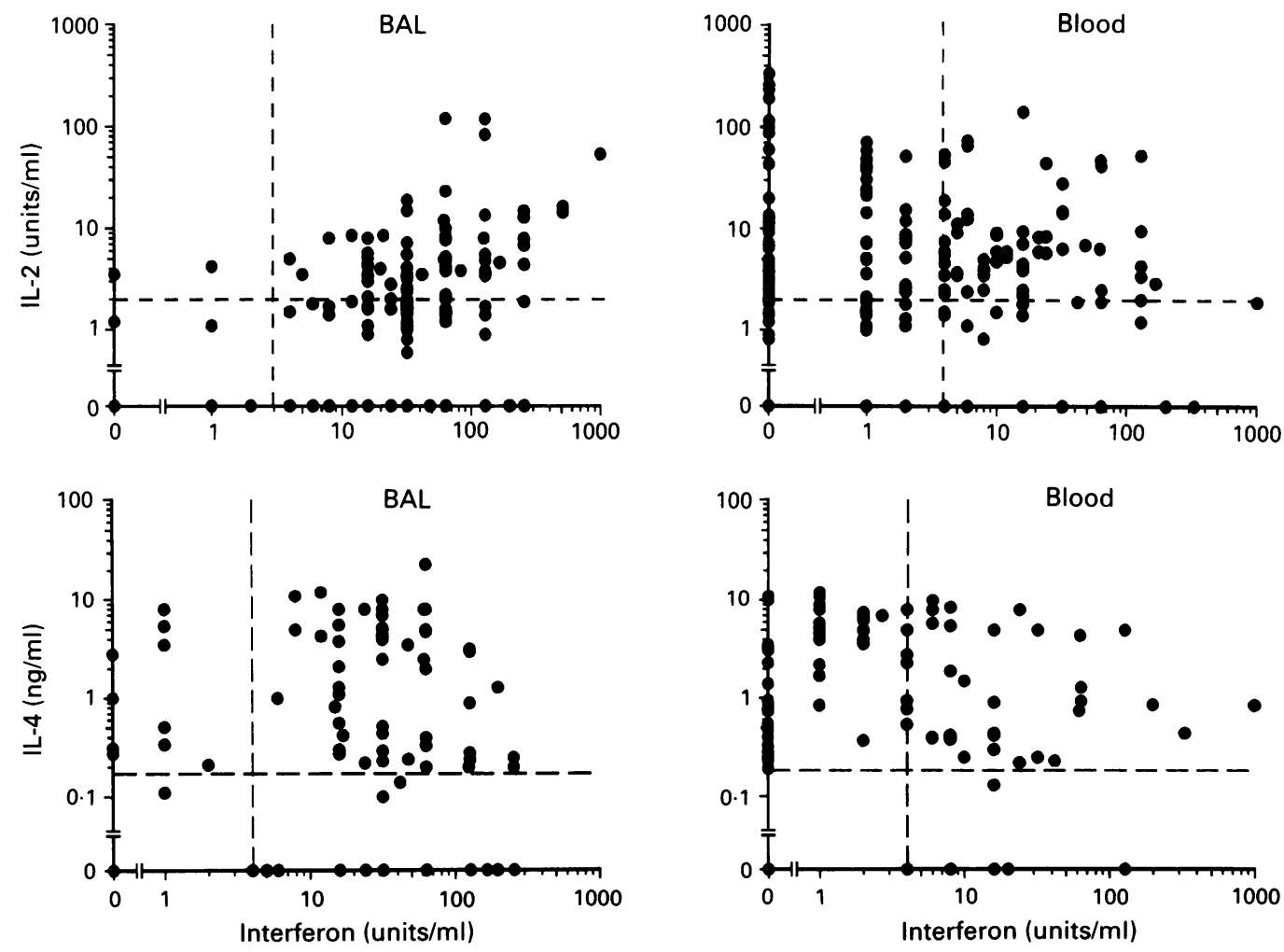

Figure 5 Distribution of CD4+ clones from BAL fluid or blood of patients with sarcoidosis according to their production of IFN $\gamma$ and IL-2 (BAL fluid, $n=145$; blood, $n=180$ ) or IFN $\gamma$ and IL-4 (BAL fluid, $n=98 ;$ blood, $n=97$ ). Some data points are superimposed. 

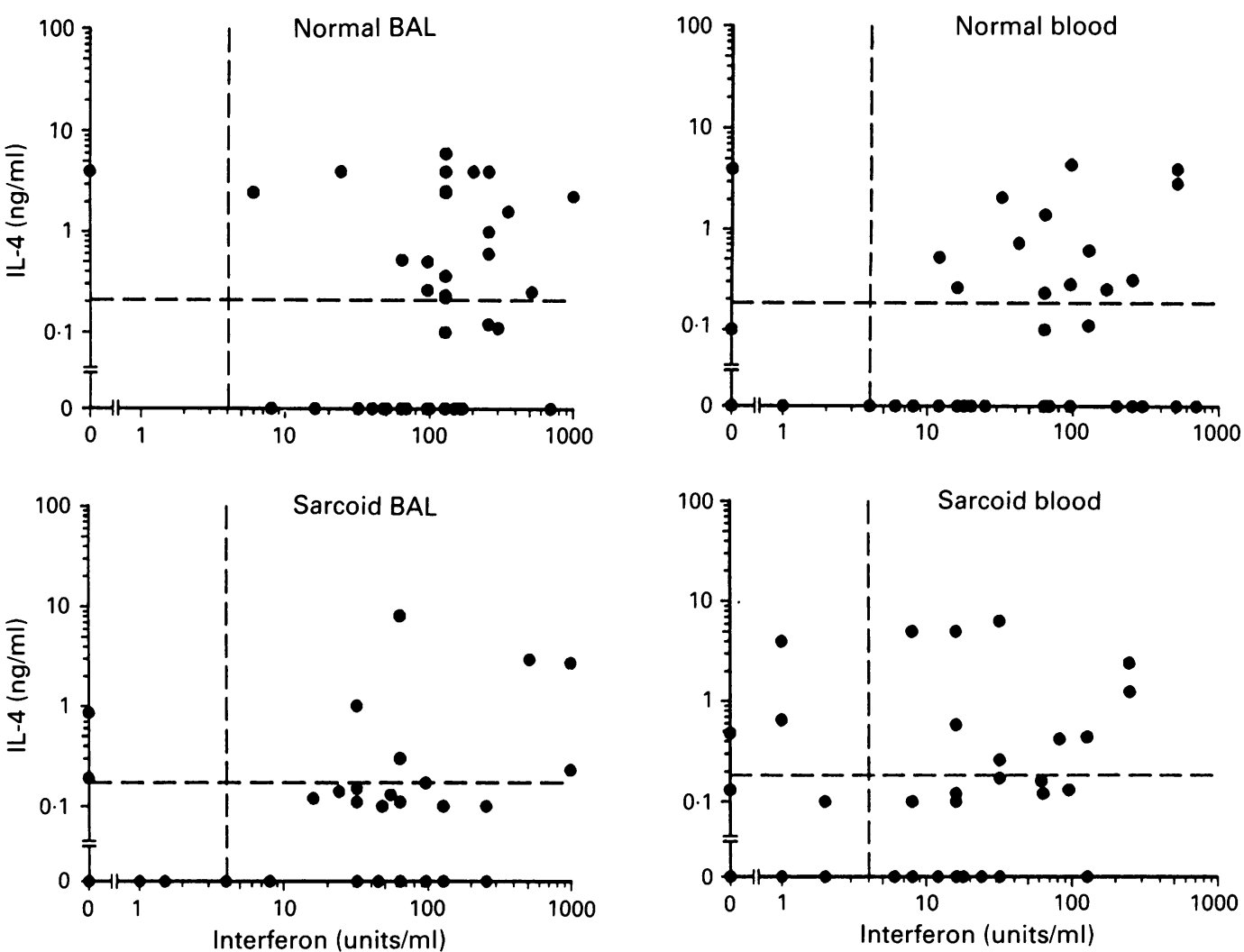

Figure 6 Distribution of CD8 + clones according to their production of IFN $\gamma$ and IL-4. The numbers of clones analysed were: normal BAL fluid, $n=38$; normal blood, $n=35$; sarcoid BAL fluid, $n=29$; sarcoid blood, $n=32$.

provides further confirmation that the lymphocyte accumulation in the lung in sarcoidosis represents part of a pathophysiological process and not merely a "leakage" of blood lymphocytes into the lung. Whether this reduced clonability is acquired before entering the lung or under the immunosuppressive influence of the lung milieu ${ }^{21}$ is unknown. Interestingly, it appears that $T$ lymphocytes derived from the BAL fluid of patients with sarcoidosis clone even less efficiently than those from normal BAL fluid, even though the cloning efficiencies of $T$ cells derived from the blood of both subject groups were similar. This reduction in proliferative response and clone precursor frequency of lung $\mathrm{T}$ cells may be due to an amplification of the suppressive effect in the lung in sarcoidosis. The number and activity of suppressive macrophages in the alveoli are increased in sarcoidosis. ${ }^{22}$ Alternatively, post-activated lymphocytes are less clonable. There is evidence for $T$ cell receptor downregulation in sarcoidosis, ${ }^{23}$ so the reduced cloning efficiency may reflect local $\mathrm{T}$ cell activation or accumulation of activated $T$ cells in the lungs. Whether the $T$ cells in the lung are in a state of partial anergy or are committed to a path towards cell death is also unknown. Data from Becker et $a l^{4}$ indicating some responsiveness to anti-CD3 and IL-2, in healthy lung $T$ cells at least, are consistent with the former.

$T$ cells freshly isolated from the lavage fluid of patients with sarcoidosis spontaneously secrete IFN $\gamma,{ }^{8}$ and those derived from patients with very active disease secrete IL-2. ${ }^{6}$ The data in the present study which show that the majority of both $\mathrm{CD} 4+$ and $\mathrm{CD} 8+$ lung clones are intrinsically capable of producing IFN $\gamma$, and that a much smaller proportion produce IL-2, may be a reflection of the less severe level of inflammation of most of the patients studied or, more likely, they may indicate that IFN $\gamma$ is produced by most lung $T$ cells in sarcoidosis whereas IL-2, when produced, is produced by a smaller proportion of these cells. This is supported by the observation that granuloma associated $\mathrm{T}$ cells predominantly produce IFN $\gamma$ rather than IL-2. ${ }^{25}$ Conversely, a greater proportion of $\mathrm{CD} 4+$ blood derived clones produced IL-2 than IFN $\gamma$. These data are consistent with our observations in healthy subjects, ${ }^{14}$ suggesting that in both patients with sarcoidosis and normal individuals the lung milieu may exert a modulating influence on recruited $T$ cells in favour of IFN $\gamma$ production or, alternatively, $\mathrm{T}$ cells of this phenotype may be selectively recruited from the blood to the lung.

$T$ cell dichotomy has been shown in several human immunological responses and diseases with an immunological basis. ${ }^{26}$ In tuberculoid leprosy Th1-like cells predominate, whereas Th2-like cells are found in the lepromatous form, ${ }^{112}$ and in cutaneous responses to purified protein derivative Thl cells are found, ${ }^{27}$ while in local atopic allergic responses Th2 cells predominate ${ }^{28}$ We hypothesised that a predominance of Thl-like $\mathrm{T}$ cell clones would be derived from the BAL fluid of sarcoidosis patients. The majority of CD4 + clones were neither Th1 nor Th2 in phenotype since they 
were capable of producing both IL-4 and IFN $\gamma$. This is consistent with previous reports in which $\mathrm{T}$ cell clones have been stimulated with mitogens. ${ }^{2930}$ Amongst clones derived from BAL fluid there was a clear population $(28 \%)$ which produced IFN $\gamma$ without IL-4, and a paucity of clones $(11 \%)$ which produced IL-4 without IFN $\gamma$. By contrast, amongst blood derived clones $48 \%$ produced IL-4 without IFN $\gamma$ (Th2-like) and only $8 \%$ produced IFN $\gamma$ alone. Analysis of the coproduction of IL-2 and IFN $\gamma$ provides further support for the differences in properties of the clones derived from the two compartments. Although many clones derived from either the BAL fluid or blood produced both IL-2 and IFN $\gamma$, it is clear that clones producing IFN $\gamma$ alone were derived primarily from the BAL fluid and clones producing IL-2, but no IFN $\gamma$, were derived primarily from the blood. These data are again consistent with data derived from healthy individuals. ${ }^{14}$

The distributions of the concentrations of IFN $\gamma$ or IL- 2 produced by clones derived from the BAL fluid of patients with sarcoidosis were not statistically different from those produced by BAL clones from normal subjects (table 2). Similarly, the blood derived clones from the two groups did not differ in their IL2 production. Clones derived from blood of patients with sarcoidosis tended to produce lower concentrations of IFN $\gamma$ than those from the blood of healthy subjects $(p<0 \cdot 02)$. Interestingly, the quantity of IFN $\gamma$ produced by the $\mathrm{CD} 8+$ clones from the blood or BAL fluid of healthy individuals was greater than that produced by $\mathrm{CD} 8$ + clones from the corresponding compartments of patients with sarcoidosis (table 2). These differences are unlikely to be a function of temporal variations in assay sensitivity since a similar comparison of CD4+ populations from the two groups of subjects (see above) showed no differences in IL-2 production by clones derived from BAL fluid or blood, and no difference in IFN $\gamma$ production by clones derived from BAL fluid.

Table 2 Comparison of cytokine production by $T$ cell clones from patients with sarcoidosis and normals

\begin{tabular}{|c|c|c|c|c|c|c|}
\hline & \multicolumn{2}{|c|}{$I F N \gamma$} & \multicolumn{2}{|c|}{$I L-2$} & \multicolumn{2}{|c|}{$I L-4$} \\
\hline & $n$ & Median & $n$ & Median & $n$ & Median \\
\hline $\begin{array}{l}\text { CD4+ BAL fluid } \\
\mathrm{S} \\
\mathrm{N} \\
\mathrm{p}\end{array}$ & $\begin{array}{r}153 \\
61\end{array}$ & $\begin{array}{l}32 \\
32 \\
\text { NS }\end{array}$ & $\begin{array}{r}153 \\
60\end{array}$ & $\begin{array}{l}1.9 \\
0.0 \\
\text { NS }\end{array}$ & $\begin{array}{r}102 \\
35\end{array}$ & $\begin{array}{l}0.3 \\
0.7 \\
\text { NS }\end{array}$ \\
\hline $\begin{array}{l}\text { CD4+ blood } \\
\mathbf{S} \\
\mathbf{N} \\
\mathrm{p}\end{array}$ & $\begin{array}{r}198 \\
77\end{array}$ & $\begin{array}{l}2 \\
4 \\
0.02\end{array}$ & $\begin{array}{r}190 \\
78\end{array}$ & $\begin{array}{l}5 \cdot 1 \\
7 \cdot 2 \\
\text { NS }\end{array}$ & $\begin{array}{r}102 \\
26\end{array}$ & $\begin{array}{l}0.9 \\
0.5 \\
\text { NS }\end{array}$ \\
\hline $\begin{array}{l}\text { CD8+ BAL fluid } \\
\mathbf{S} \\
\mathbf{N} \\
\mathrm{p}\end{array}$ & $\begin{array}{l}34 \\
50\end{array}$ & $\begin{array}{c}40 \\
128 \\
0.01\end{array}$ & $\begin{array}{l}34 \\
48\end{array}$ & $\begin{array}{l}2 \cdot 2 \\
6 \cdot 6 \\
<0.01\end{array}$ & $\begin{array}{l}29 \\
38\end{array}$ & $\begin{array}{l}0 \cdot 1 \\
0 \cdot 2 \\
\text { NS }\end{array}$ \\
\hline $\begin{array}{l}\text { CD8 + blood } \\
\text { S } \\
\mathbf{N} \\
\mathrm{p}\end{array}$ & $\begin{array}{l}52 \\
42\end{array}$ & $\begin{array}{l}16 \\
64 \\
<0.005\end{array}$ & $\begin{array}{l}46 \\
43\end{array}$ & $\begin{array}{l}1.6 \\
5.8 \\
0.01\end{array}$ & $\begin{array}{l}32 \\
38\end{array}$ & $\begin{array}{l}0.1 \\
0.0 \\
\text { NS }\end{array}$ \\
\hline
\end{tabular}

$\mathrm{S}=$ sarcoidosis, $\mathrm{N}=$ normal

$\mathrm{p}$ value derived by comparing ranges of cytokine concentrations using the Wilcoxon rank sum

Cytokine concentrations are expressed in the same units as described in Methods section. Data on normal individuals were taken from our previously published work $^{14}$ and from CD $8+$ data presented in this paper.

Median values are shown since these reflect the wide distribution of cytokine concentrations (see figs $3-6$ for concentration ranges)
In summary, this study has confirmed that $T$ lymphocytes derived from the lungs of patients with pulmonary sarcoidosis are less readily clonable than those from autologous peripheral blood. These data are consistent with the properties of $T$ cells derived from BAL fluid of healthy lungs, although the reduced proliferative capacity seems to be more pronounced in the lungs of patients with sarcoidosis, suggesting either suppression or anergy. Major differences also exist in the cytokine producing potential of $\mathrm{T}$ cells derived from the lung and the blood, and again these parallel the differences in the properties of blood and lung $T$ cells seen in healthy individuals. No evidence for a shift to Th1 phenotype was seen.

This work was supported by a grant from the National Health and Medical Research Council of Australia. We thank Ms Margaret Baron-Hay for her assistance with the IL-2 bioassay.

1 Crystal RG, Bitterman PB, Rennard SI, Hance AJ, Keogh BA. Interstitial lung disease of unknown etiology: disorders characterised by chronic inflammation of the lower respiratory tract. $N$ Engl f Med 1984;310:154-66.

2 Hunninghake GW, Crystal RG. Pulmonary sarcoidosis: a disorder mediated by excess helper T-lymphocyte activity at sites of disease activity. $N$ Engl $\mathcal{F}$ Med 1981;305:42934.

3 Robinson BWS, Rose AH, Thompson PJ, Hey A. Comparison of bronchoalveolar lavage helper/suppressor T-cell ratios in sarcoidosis versus other interstitial lung diseases. Aust NZ 7 Med 1987; 17:9-15.

4 Costabel U, Bross KJ, Ruhle KH, Lohr GW, Matthys H. Ia-like antigens on T-cells and their subpopulations in pulmonary sarcoidosis and in hypersensitivity pneumonitis: analysis of bronchoalveolar and blood lymphocytes. Am Rev Respir Dis 1985;131:337-42.

5 Semenzato G, Agostino C, Trentin L, Zambello R, Chilosi $\mathrm{M}$, Cipriani A, et al. Evidence of cells bearing interleukin2 receptors at sites of disease activity in sarcoidosis patients. Clin Exp Immunol 1984;57:331-7.

6 Pinkston P, Bitterman PB, Crystal RG. Spontaneous release of IL-2 by lung T-lymphocytes in active pulmonary sarcoidosis. N Engl $\mathcal{F}$ Med 1983;308:793-800.

7 Hunninghake GW, Bedell GN, Zavala DC, Monick M, Brady $M$. Role of IL-2 release by lung T cells in active pulmonary sarcoidosis. Am Rev Respir Dis 1983;128:634-

8 Robinson BWS, McLemore TL, Crystal RG. Gamma interferon is spontaneously released by alveolar macrophages and lung $T$ lymphocytes in patients with pulmonary sarcoidosis. F Clin Invest 1985;75:1488-95.

9 Hunninghake GW, Gadek JE, Young RC, Kawanami O, Ferrans VJ, Crystal RG. Maintenance of granuloma formation in pulmonary sarcoidosis by $\mathrm{T}$ lymphocytes within the lung. $N$ Engl $f$ Med 1980;302:594-8.

10 Mosmann TR, Cherwinski H, Bond MW, Giedlin MA, Coffman RL. Two types of murine helper T-cell clone. 1 . Definition according to the profiles of lymphokine activities and secreted proteins. F Immunol 1986;136:2348-57.

11 Yamamura M, Umemura K, Deans RJ, Weinberg K, Rea $\mathrm{TH}$, Bloom BR, et al. Defining protective response to pathogens: cytokine profiles in leprosy lesions. Science 1991;254:277-9.

12 Salgame $\mathrm{P}$, Abrams JS, Clayberger C, Goldstein H, Convit $\mathrm{J}$, Modlin RL, et al. Differing lymphokine profiles of $\mathrm{J}$, Modlin RL, et al. Differing lymphokine profiles of functional subsets of human $1991 ; 254: 279-81$.

13 Del Prete GF, De Carli M, Mastromauro C, Biagliotti R, Macchia D, Falagiani $P$, et al. Purified protein derivative of Mycobacterium tuberculosis and excretory-secretory antigen(s) of Toxocar a canis expand in vitro human T cells with stable and opposite (type $1 \mathrm{~T}$ helper or type $2 \mathrm{~T}$ helper) profile of cytokine production. 7 Clin Invest 1991;88:346-50.

14 Garlepp MJ, Rose AH, Bowman RV, Mavaddat N, Dench $\mathrm{J}$, Holt BJ, et al. A clonal analysis of lung $\mathrm{T}$ cells derived by bronchoalveolar lavage of healthy individuals. Immunology $1992 ; 77: 31-7$.

15 Scadding JG, Mitchell DN. Sarcoidosis. 2nd ed. London: Chapman and Hall, 1985:247.

16 Robinson BWS, James A, Rose AH, Sterrett GF, Musk AW. Bronchoalveolar lavage sampling of airway and AW. Bronchoalveolar lavage sampling of airway and

17 Henry CJ, Marbrook J, Vann C, Kodlin D, Wofsy C. Limiting dilution analysis. In: Mishell BB, Shiigi SM, eds. Selected methods in cellular immunology. San Francisco: WH Freeman, 1980:138-46.

18 Holt PG, Kees UR, Schon-Hegrad M, Rose A, Bilyk N, Bowman $\mathrm{R}$, et al. Limiting dilution analysis of $\mathrm{T}$-cells extracted from solid human lung tissue: comparison of precursor frequencies for proliferative responses and lymphokine production between lung and blood T-cells from individual donors. Immunology 1988;34:649-55. 
19 Epstein LB, McManus NH, Herbert SJ, Woods-Hellman J, Oliver DG. Microtiter assay for antiviral effects of human and murine interferon utilising vertical path photometer for quantitation. In: Adams DO, Edelson PJ, Koren H, eds. Methods for studying mononuclear phagocytes. New York: Academic Press, 1981:619-28.

20 Le Cossier D, Valeyre D, Loiseau A, Battesti JP, Soler P, Hance AJ. T-lymphocytes recovered by bronchoalveolar lavage from normal subjects and patients with sarcoidosis are refractory to proliferative signals. Am Rev Respir Dis 1988;137:592-9.

21 Holt PG, McMenamin C, Schon-Hegrad M, Strickland D, Nelson D, Wilkes L, et al. Immunology of asthma: control of $\mathrm{T}$ lymphocyte activation in the respiratory tract. Eur Respir f 1991;4:S6-15.

22 Spiteri MA, Clarke SW, Poulter LW. Alveolar macrophages that suppress $T$ cell responses may be crucial to the pathogenetic outcome of pulmonary sarcoidosis. Eur Respir f 1992;5:394-403.

23 Du Bois RM, Kirby M, Saltini C, Crystal RG. T-lymphocytes that accumulate in the lung in sarcoidosis have evidence of recent stimulation of the $T$-cell antigen receptor. Am Rev Respir Dis 1992;145:1205-11.

24 Becker S, Harris DT, Koren HS. Characterisation of nor- mal human lung lymphocytes and interleukin-2-induced lung T cell lines. Am 7 Respir Cell Mol Biol 1990;3:441-8. 25 Asano M, Minagawa T, Ohmichi M, Hiraga Y. Detection of endogenous cytokines in sera or in lymph nodes obtained from patients with sarcoidosis. Clin Exp nol 1991;84:92-6.

26 Romagnini S. Human $\mathrm{TH} 1$ and $\mathrm{TH} 2$ subsets: doubt no more. Immunol Today 1991;12:256-7.

27 Kay AB, Ying S, Varney V, Gaga M, Durham SR, Moqbel $\mathrm{R}$, et al. Messenger RNA expression of the cytokine gene cluster, interleukin-3 (IL-3), IL-4, IL-5, and granulocyte/macrophage colony-stimulating factor in allergeninduced late phase cutaneous reactions in atopic asthma. $\mathcal{f}$ Exp Med 1991;173:775-8.

28 Robinson DS, Hamid Q, Ying S, Tsicopoulos A, Barkans J, Bentley AM, et al. Predominant TH2-like bronchoalveolar T lymphocyte population in atopic asthma. $N$ Engl $\mathcal{F}$ Med 1992;326:298-304.

29 Patel SG, Duby AD, Thiele DL, Lipsky PE. Phenotypic and functional characteristics of human $\mathrm{T}$ cell clones. $\mathcal{F}$ Immunol 1988;141:3726-42.

30 Paliard X, De Waal Malefitt R, Yssel H, Blanchard D, Chretien I, Abrams J, et al. Simultaneous production of IL-2, IL- 4 and IFN- $\gamma$ by activated human CD $4+$ and CD8 + T cell clones. $\mathcal{f}$ Immunol 1988;141:849-55. 